\title{
Soluble toll like receptor 2 (TLR-2) is increased in saliva of children with dental caries
}

\author{
Alyssa Zhao ${ }^{1}$, Corinne Blackburn ${ }^{1}$, Judith Chin $^{2}$ and Mythily Srinivasan ${ }^{1 *}$
}

\begin{abstract}
Background: Dental caries is the most common microbial disease affecting mankind. Caries risk assessment methods, identification of biomarkers and vaccine development strategies are being emphasized to control the incidence of the largely preventable disease. Pattern recognition receptors such as the toll like receptors (TLR) have been implicated as modulators of host-microbial interactions. Soluble TLR-2 and its co-receptor, CD14 identified in saliva can bind the cell wall components of cariogenic bacteria and modulate the disease process. The objective of this study is to determine the potential of salivary sTLR-2 and SCD14 as biomarkers of caries activity and indirect measures of the cariogenic bacterial burden.
\end{abstract}

Methods: Unstimulated whole saliva was collected from twenty caries free and twenty caries active children between the ages of 5 and 13 years. The concentration of SCD14 and STLR-2 together with that of the cytokine IL-8 reported to be increased in dental caries was assessed by the enzyme linked immunosorbent assay.

Results: While the level of sCD14 and that of IL-8 was equivocal between the two groups, the sTLR-2 concentration in caries active saliva was significantly higher than that in caries free saliva.

Conclusions: The sTLR-2 in saliva could serve as a potential biomarker for caries activity.

Keywords: Saliva, Soluble toll like receptor 2, Dental caries, Biomarker

\section{Background}

Dental caries is a multifactorial infectious disease caused by complex interactions between the acid-producing bacteria, fermentable carbohydrates and host factors. Despite being largely preventable, it remains as the most prevalent chronic disease globally [1]. Recent systematic analyses suggest that the incidence of caries exhibits an increasing trend in children aged 2-4 years in the United States [2]. There is evidence for increased prevalence in adults in lower socioeconomic status in European countries. In developing nations the prevalence is increasing in both children and adults [3].

Early detection of white-spot lesions, arresting demineralization and promoting remineralization are some of the preventive clinical methods currently used in dental caries management [4]. In addition considerable emphasis is placed on developing efficient caries risk assessment strategies to determine the likelihood of an

\footnotetext{
* Correspondence: mysriniv@iu.edu

'Department of Oral Pathology, Medicine and Radiology, Indianapolis, IN 46202, USA

Full list of author information is available at the end of the article
}

individual developing new carious lesion and/or to determine the status of the caries process on individual tooth surfaces $[4,5]$. As disease of the mineralized tissues of the teeth, pathogenesis of caries involves demineralization of enamel by acid producing bacteria and destruction of the organic substance resulting in cavitation $[1,4]$.

Saliva is recognized as a rich source of host factors capable of modulating the caries process [6,7]. Technological advancements have aided in the characterization of salivary proteomics and peptidomics with the identification of 1444 proteins and 11893 peptides respectively [8]. These protein/peptides belong to different functional classes such as those involved in response to stimulus/ stress, antioxidant functions, catalytic functions and enzyme regulators $[8,9]$. Several salivary components have been assessed for an association with dental caries. While some exhibit weak association, others were equivocal between normal and caries active saliva [9-12]. Assessment of salivary glycoproteins with specific oligosaccharides showed that higher levels of select oligosaccharide 
that facilitate bacterial colonization at the surface of teeth correlate with caries incidence in young adults [13]. Salivary levels of antimicrobial agents such as alpha defensins, statherin and cystatin $S$ have been suggested as potential risk factors for caries development $[10,14]$.

Toll like receptors (TLR) are germ line encoded receptors that recognize conserved microbial patterns typically shared by large groups of microorganisms. Currently 13 mammalian TLRs and many of their ligands are known [15]. Functioning either alone or in concert with specific co-receptors in recognizing microbial patterns the TLRs act as gate-keepers constantly sampling the environment and eliciting responses to prevent/control infection $[15,16]$. TLR-2 and TLR-4 have been shown to recognize the peptidoglycan of Gram positive and the lipopolysaccharide of the Gram negative bacteria respectively either alone or in association with the common co-receptor CD14 $[17,18]$. Odontoblasts localized at the dentino-pulpal surface in healthy teeth have been shown to express TLR-2 and TLR-4. Depending upon the nature of the odontoblastic response caries progression is either suppressed with the formation of reactionary dentin or accelerated leading to pulpal inflammation $[19,20]$. Microbial invasion of dentin has been shown to upregulate TLR-4 in odontoblasts and mediate TGF- $\beta$ secretion facilitating collagen synthesis. In addition TLR-4 signaling in odontoblasts also upregulate matrix metalloproteinase- 2 promoting cleavage of dentin sialophosphoprotein (DSPP) to dental sialoprotein (DSP) which forms a nucleation site for hydroxyapeptite crystal formation in the newly formed collagen [19]. Stimulation of odontoblast like cells with cell wall components of Gram-positive bacteria elicited cytokine and chemokine secretions in a TLR-2 dependent manner [20]. Elevated levels of cytokines IL-6, TNF- $\alpha$ and IL- 8 have been observed in caries active saliva [21].

While primarily membrane associated, recently soluble forms of certain TLRs have been identified in body fluids. It has been suggested that the soluble TLRs function to sequester pathogens [22-25]. Recently, we and others have reported the presence of soluble SCD14 and sTLR-2 in saliva [24,26]. TLR-2 has been shown to recognize the peptidoglycan and the lipotechoic acid of Streptococcus mutans, the most common cariogenic bacteria [27]. Considerable evidence suggests a strong correlation between the increased presence of cariogenic bacteria in the plaque biofilm and elevated numbers of the same bacteria in saliva $[6,10]$. Hence we hypothesized that the level of sTLR-2 and sCD14 in the saliva of caries active individuals will yield an indirect measure of the bacterial burden and act as a biomarker of caries activity. Our data suggest that the sTLR-2 is higher in the unstimulated whole saliva (UWS) of children with active caries lesions.

\section{Methods}

\section{Study population}

In this prospective non-randomized clinical study forty children between 6 and 12 years of age reporting to the pediatric clinics of the Indiana University School of Dentistry were recruited after obtaining informed consent from the patients and guardian. The study was approved by the Institutional Review Board of the Indiana University Purdue University at Indianapolis. Samples were collected only from children with no known oral or systemic disease other than dental caries and no extracted teeth. Oral examinations of children were performed and caries activity recorded. Twenty children (13 boys and 7 girls) were caries free and twenty children (12 boys and 8 girls) were caries active exhibiting four to eight carious lesions requiring restoration.

\section{Sample collection and processing}

All children were instructed to avoid eating and drinking for at least $2 \mathrm{hr}$ prior to saliva collection as described $[24,28]$. After rinsing the mouth briefly with water, unstimulated whole saliva (UWS) was collected from each child by the passive drooling method for five minutes in pre-chilled tubes. The samples were transported on ice to the laboratory immediately for processing. Each sample was clarified by centrifuging at $4000 \mathrm{xg}$ at $4^{\circ} \mathrm{C}$ for 10 mins and stored in three aliquots at $-80^{\circ} \mathrm{C}$ in CompleteTM Protease Inhibitor Cocktail (Roche, Mannheim, Germany) until further analysis.

\section{Total protein concentration}

The total protein content of pre samples was measured by the Bradford method that involves binding of Commassie blue dye to the proteins $[24,25]$. The blue protein-dye form was detected at $595 \mathrm{~nm}$ using spectrophotometer (Gensys5 spectrophotometer, Thermoelectronic corp, CA). The concentration of the protein in each sample was determined against a standard curve developed using known concentration of bovine serum albumin.

\section{Enzyme linked immunosorbent assay (ELISA)}

For determining sCD14 in saliva a sandwich ELISA kit (R\&D Systems, Minneapolis, MN) was used according to manufacturer's recommendations. Anti-human TLR-2 polyclonal antibody (clone: Imgenex Corporation, San Diego, CA) was used for detection of TLR-2. All UWS

Table 1 The demographic data of the study population

\begin{tabular}{llll}
\hline Clinical Data & \multicolumn{2}{c}{ Number recruited } & Age (yrs) \\
\cline { 2 - 3 } & Male & Female & \\
\hline Dental caries & 12 & 8 & $8.76+/-3.42$ \\
Healthy control & 13 & 7 & $7.77+/-2.7$ \\
\hline
\end{tabular}



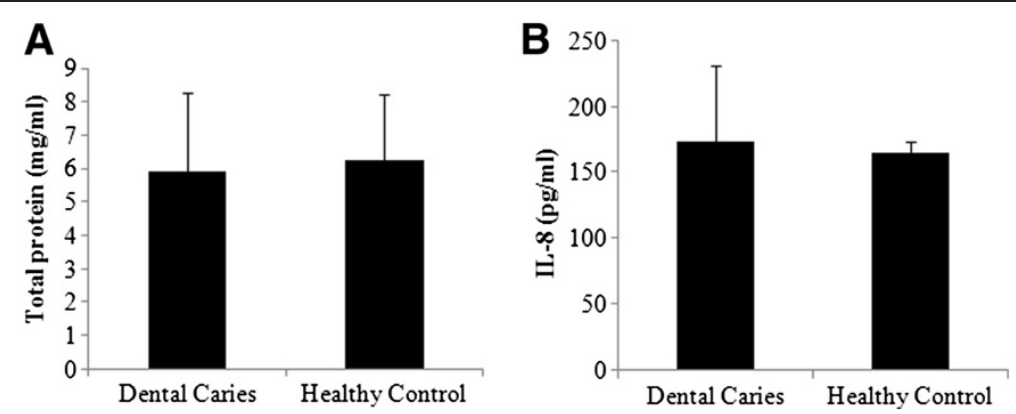

Figure 1 Total protein concentration in saliva: Clarified whole saliva was assessed for (A) total protein content by spectrophotometry and (B) IL-8 concentration by ELISA. No significant difference was observed between the caries free and the caries active saliva groups.

samples were depleted of amylase and immunoglobulins by incubating serially with anti-human amylase monoclonal antibody (mAb) (1:2500, catalog \#ab8944; Abcam, Cambridge, MA, USA) and protein G beads (Miltenyi Biotec Inc Auburn, CA) at $4^{\circ} \mathrm{C}$ [24]. The protein content of the precleaned samples was determined as above and precleaned UWS at $1 \mu \mathrm{g} / \mathrm{ml}$ concentration was used for measuring sCD14 and sTLR-2 levels [25]. Preincubation of the UWS with either anti-TLR2 mAb (clone: 1030A5.138, Imgenex Corp, San Diego, CA, USA) $(0.5 \mu \mathrm{g} / \mathrm{ml})$ or with TLR-2 peptides $(1 \mu \mathrm{g} / \mathrm{ml})$ was performed to evaluate the specificity of binding. Bound CD14 and TLR-2 was detected with horse radish peroxidase (HRP) conjugated anti-mouse IgG followed by TMB substrate (Pharmingen, San Diego, CA). Absorbance at $450 \mathrm{~nm}$ was read in a microplate reader (model 680: Biorad Laboratories, CA). The concentration of sTLR-2 or $\mathrm{sCD} 14 \mathrm{in} \mathrm{pg} / \mathrm{ml}$ of salivary proteins was determined using a standard curve of purified recombinant human CD14Fc and TLR-2Fc (R\&D Systems) of known concentration. IL-8 concentration in the clarified saliva samples were measured using BD OptEIA3 ${ }^{\mathrm{Tm}}$ ELISA kit.

\section{Statistical analysis}

Differences in the concentration of IL-8, CD14 and TLR-2 between the caries free and caries active groups were determined by Students' t-test. $\mathrm{p}$ value less than 0.05 was considered significant.

\section{Results and discussion}

Despite advances in early detection methods and efficient preventive measures dental caries remains a highly prevalent chronic disease worldwide. The increasing incidence amongst children in developed countries constitutes a disturbing health concern $[2,3]$. The demographic details of the study population are given in Table 1. The total protein concentration of human saliva has been shown to exhibit large variations ranging from $0.4 \mathrm{mg} / \mathrm{ml}$ to $7.1 \mathrm{mg} / \mathrm{ml}[29,30]$. In our study cohort the total protein concentration measured $6.24+/-1.98 \mathrm{mg} / \mathrm{ml}$ in caries free saliva and $5.92+/-2.37 \mathrm{mg} / \mathrm{ml}$ in caries active saliva (Figure 1A).

To the increasing number of salivary proteins are added the soluble forms of pattern recognition receptors, the sTLR-2, sCD14 and sTLR-4 [25,26,31]. The concentration of sTLR-2 in parotid saliva has been reported to be several folds higher than in whole saliva [31]. The source of sTLR-2 could be either active secretion from the gland and/or a result of extracellular cleavage of the membrane bound receptor. We observed that the concentration of sTLR-2 in caries active saliva $(29.5+/-3$ $\mathrm{pg} / \mathrm{ml}$ ) was significantly higher than that in caries free
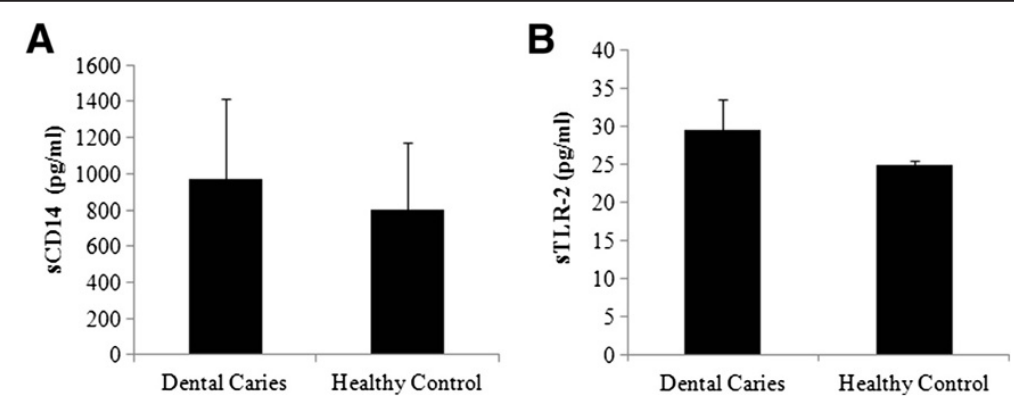

Figure 2 sCD14 and sTLR-2 concentration in saliva: Clarified saliva was depleted of the high molecular weight abundant proteins, amylase and immunoglobulins, as described in the methods section to increase the sensitivity of detecting of less abundant sCD14 and sTLR-2. The level of (A) sCD14 and (B) sTLR-2 was determined by ELISA. * represents $p<0.05$. 
saliva $(24.8+/-0.6 \mathrm{pg} / \mathrm{ml})$ (Figure 2B). Signaling via TLRs in host cells induces cytokine secretion [15]. Previously Gornowicz et al., have reported elevated levels of salivary IL-8 in dental caries [21]. We observed that the salivary IL-8 concentration did not differ significantly between caries free and caries active saliva (Figure 1B). The variable observation between the two studies could be attributed to the differences in the age and the nature of the sample (amylase and Ig depleted vs. undepleted). The concentration of sCD14 in saliva was equivocal in both groups; ranging between $509 \mathrm{pg} / \mathrm{ml}$ and $1443 \mathrm{pg} / \mathrm{ml}$ in caries free group and between $609 \mathrm{pg} / \mathrm{ml}$ and $1829 \mathrm{pg} / \mathrm{ml}$ in caries active group (Figure 2A). Previously Bergandi et al., reported complete absence of $\mathrm{SCD} 14$ in saliva in children with two to eight carious lesions [28]. The use of pre-cleaned saliva and the method used for measuring sCD14 (Western blot versus sandwich ELISA) could attribute to the observed differences between the Bergandi report and our study.

Based on its strong association with caries incidence multiple studies evaluated salivary levels of S.mutans for caries risk prediction with variable results [1,32]. The polymicrobial etiology of dental caries as well as the interaction between salivary proteins and S.mutans could contribute to the variability [30,33]. Four major types of salivary protein-microbe interaction have been observed in vitro. These include aggregation, adherence, inhibition/cell-killing, and nutrition [33]. It is postulated that the observed increase in sTLR-2 in caries active saliva may represent a host measure to combat the increased Gram + ve cariogenic bacteria. This suggests that the salivary sTLR-2 level may represent an efficient biomarker for caries activity. The wide variation in the sTLR-2 concentration in caries active saliva could be due to the extent of caries.

\section{Conclusions}

Dental caries is a complex disease, the clinical severity of which depends on the interaction between oral microbes, availability of fermentable carbohydrates and host factors in saliva. This makes identification of predictive risk factors for the carious process very difficult $[5,6]$. In this report we observed that two soluble proteins, SCD14 and sTLR-2, that act at the microbial host interface are modified in caries active saliva with a later representing a potential biomarker for caries activity. Future studies will correlate the sTLR-2 levels with the cariogenic bacterial counts in saliva.

\section{Abbreviations}

UWS: Unstimulated whole saliva; TLR: Toll like receptor.

\section{Competing interests}

The authors declare that they have no competing interest.

\section{Authors' contributions}

AZ: Alyssa is a high school sophomore who carried out the ELISA experiments as part of the summer research scholarship program, the Project Seed, co-sponsored by the American Chemical Society and the Indiana Clinical Translations Sciences Institute. She also wrote the first draft of the "Background" section. CB: Corinne is an undergraduate research assistant who helped Alyssa in conducting the ELISA experiments, more so in data analysis. She actively participated in sample processing. She also participated in manuscript writing. JC: Dr. Chin is the pediatric dentist and assisted in the recruitment of study population and sample collection. MS: is the senior investigator overseeing the project including obtaining ethical approvals, experimental design, and data analysis and manuscript preparation. All authors read and approved the final manuscript.

\section{Acknowledgement}

The authors acknowledge the support provided to Alyssa Zhao by the Indiana CTSI to complete the summer research program.

\section{Author details}

'Department of Oral Pathology, Medicine and Radiology, Indianapolis, IN 46202, USA. ${ }^{2}$ Department of Pediatric Dentistry, Indiana University School of Dentistry, Indianapolis, IN 46202, USA.

Received: 28 January 2014 Accepted: 18 August 2014

Published: 31 August 2014

\section{References}

1. Smith DJ: Dental caries vaccines: prospects and concerns. Crit Rev Oral Biol Med 2002, 13(4):335-349.

2. Do LG: Distribution of caries in children: variations between and within populations. J Dent Res 2012, 91(6):536-543.

3. Costa SM, Martins CC, Bonfim Mde L, Zina LG, Paiva SM, Pordeus IA, Abreu MH: A systematic review of socioeconomic indicators and dental caries in adults. Int J Environ Res Public Health 2012, 9(10):3540-3574.

4. Anusavice KJ: Present and future approaches for the control of caries. J Dent Educ 2005, 69(5):538-554.

5. Hallett KB: The application of caries risk assessment in minimum intervention dentistry. Aust Dent J 2013, 58(Suppl 1):26-34.

6. Lencova E, Broukal Z, Spizek J: Point-of-care salivary microbial tests for detection of cariogenic species-clinical relevance thereof-review. Folia Microbiol 2010, 55(6):559-568

7. Martins C, Buczynski AK, Maia LC, Siqueira WL, Castro GF: Salivary proteins as a biomarker for dental caries-a systematic review. J Dent 2013, 41(1):2-8.

8. Yan W, Apweiler R, Balgley BM, Boontheung P, Bundy JL, Cargile BJ, Cole S, Fang X, Gonzalez-Begne M, Griffin TJ, Hagen F, Wolinsky LE, Lee CS, Malamud D, Melvin JE, Menon R, Mueller M, Qiao R, Rhodus NL, Sevinsky JR, States D, Stephenson JL, Than S, Yates JR, Yu W, Xie H, Xie Y, Omenn GS, Loo JA, Wong DT: Systematic comparison of the human saliva and plasma proteomes. Proteomics Clin Appl 2009, 3(1):116-134

9. Ribeiro TR, Dria KJ, de Carvalho CB, Monteiro AJ, Fonteles MC, de Moraes CK, Fonteles CS: Salivary peptide profile and its association with early childhood caries. Int I Paediatr Dent 2013, 23(3):225-234.

10. Guo L, Shi W: Salivary biomarkers for caries risk assessment. I Calif Dent Assoc 2013, 41(2):107-109. 112-108.

11. Tenovuo J: Salivary parameters of relevance for assessing caries activity in individuals and populations. Community Dent Oral Epidemiol 1997, 25(1):82-86.

12. Tulunoglu O, Demirtas S, Tulunoglu I: Total antioxidant levels of saliva in children related to caries, age, and gender. Int J Paediatr Dent 2006, 16(3):186-191.

13. Denny PC, Denny PA, Takashima J, Si Y, Navazesh M, Galligan JM: A novel saliva test for caries risk assessment. J Calif Dent Assoc 2006, 34(4):287-290. 292-284.

14. Dale BA, Tao R, Kimball JR, Jurevic RJ: Oral antimicrobial peptides and biological control of caries. BMC Oral Health 2006, 6(Suppl 1):S13.

15. Takeda K, Kaisho T, Akira S: Toll-like receptors. Annu Rev Immunol 2003, 21:335-376

16. Pulendran B, Palucka K, Banchereau J: Sensing pathogens and tuning immune responses. Science 2001, 293(5528):253-256. 
17. Kirschning CJ, Schumann RR: TLR2: cellular sensor for microbial and endogenous molecular patterns. Curr Top Microbiol Immunol 2002, 270:121-144.

18. Moreillon P, Majcherczyk PA: Proinflammatory activity of cell-wall constituents from gram-positive bacteria. Scand J Infect Dis 2003, 35(9):632-641.

19. Charadram N, Farahani RM, Harty D, Rathsam C, Swain MV, Hunter N: Regulation of reactionary dentin formation by odontoblasts in response to polymicrobial invasion of dentin matrix. Bone 2012, 50(1):265-275,

20. Farges JC, Carrouel F, Keller JF, Baudouin C, Msika P, Bleicher F, Staquet MJ: Cytokine production by human odontoblast-like cells upon Toll-like receptor-2 engagement. Immunobiology 2011, 216(4):513-517.

21. Gornowicz A, Bielawska A, Bielawski K, Grabowska SZ, Wojcicka A, Zalewska M, Maciorkowska E: Pro-inflammatory cytokines in saliva of adolescents with dental caries disease. Ann Agric Environ Med 2012, 19(4):711-716.

22. Iwami Kl, Matsuguchi T, Masuda A, Kikuchi T, Musikacharoen T, Yoshikai Y: Cutting edge: naturally occurring soluble form of mouse Toll-like receptor 4 inhibits lipopolysaccharide signaling. J Immunol 2000, 165(12):6682-6686.

23. LeBouder E, Rey-Nores JE, Rushmere NK, Grigorov M, Lawn SD, Affolter M, Griffin GE, Ferrara P, Schiffrin EJ, Morgan BP, Labeta MO: Soluble forms of Toll-like receptor (TLR)2 capable of modulating TLR2 signaling are present in human plasma and breast milk. J Immunol 2003, 171(12):6680-6689.

24. Srinivasan M, Kodumudi KN, Zunt SL: Soluble CD14 and toll-like receptor-2 are potential salivary biomarkers for oral lichen planus and burning mouth syndrome. Clin Immunol 2008, 126(1):31-37.

25. Zunt SL, Burton LV, Goldblatt LI, Dobbins EE, Srinivasan M: Soluble forms of Toll-like receptor 4 are present in human saliva and modulate tumour necrosis factor-alpha secretion by macrophage-like cells. Clin Exp Immunol 2009, 156(2):285-293.

26. Isaza-Guzman DM, Aristizabal-Cardona D, Martinez-Pabon MC, VelasquezEcheverri H, Tobon-Arroyave SI: Estimation of sCD14 levels in saliva obtained from patients with various periodontal conditions. Oral Dis 2008, 14(5):450-456.

27. Hong SW, Baik JE, Kang SS, Yun CH, Seo DG, Han SH: Lipoteichoic acid of Streptococcus mutans interacts with Toll-like receptor 2 through the lipid moiety for induction of inflammatory mediators in murine macrophages. Mol Immunol 2014, 57(2):284-291.

28. Bergandi L, Defabianis P, Re F, Preti G, Aldieri E, Garetto S, Bosia A, Ghigo D: Absence of soluble CD14 in saliva of young patients with dental caries. Eur J Oral Sci 2007, 115(2):93-96.

29. Chiappin S, Antonelli G, Gatti R, De Palo EF: Saliva specimen: a new laboratory tool for diagnostic and basic investigation. Clin Chim Acta 2007, 383(1-2):30-40.

30. Rudney JD: Does variability in salivary protein concentrations influence oral microbial ecology and oral health? Crit Rev Oral Biol Med 1995, 6(4):343-367.

31. Kuroishi T, Tanaka Y, Sakai A, Sugawara Y, Komine K, Sugawara S: Human parotid saliva contains soluble toll-like receptor (TLR) 2 and modulates TLR2-mediated interleukin-8 production by monocytic cells. Mol Immunol 2007, 44(8):1969-1976.

32. Pitts N, Duckworth RM, Marsh P, Mutti B, Parnell C, Zero D: Post-brushing rinsing for the control of dental caries: exploration of the available evidence to establish what advice we should give our patients. Br Dent J 2012, 212(7):315-320.

33. Scannapieco FA: Saliva-bacterium interactions in oral microbial ecology. Crit Rev Oral Biol Med 1994, 5(3-4):203-248.

\section{Submit your next manuscript to BioMed Central and take full advantage of:}

- Convenient online submission

- Thorough peer review

- No space constraints or color figure charges

- Immediate publication on acceptance

- Inclusion in PubMed, CAS, Scopus and Google Scholar

- Research which is freely available for redistribution

Submit your manuscript at www.biomedcentral.com/submit 